\title{
Determinants of voluntary web-based disclosure: A comparison of the united kingdom and its former colony, New Zealand
}

\author{
Hanen Ghorbel Siala ${ }^{1}$, Yosra Mnif Sellami ${ }^{2}$, Hela Borgi Fendri ${ }^{3}$ \\ ${ }^{1}$ Department of Accounting, High School of Business of Sfax, Sfax University, Tunisia \\ ${ }^{2}$ Department Accounting, Taxation and Law in High Institute of Business Administration of Sfax, Sfax University, Tunisia \\ ${ }^{3}$ Accounting researcher \\ *Corresponding author E-mail: yosra.mnif.sellami.isaas@gmail.com
}

\begin{abstract}
The paper represents an attempt of enrichment of researches relating to the publication of Voluntary Information Disclosure on the WebSites (VDWS). The main objective of this research is to compare the extent of VDWS and the differential impact of some firm specific characteristics in the United Kingdom and New Zealand on firms' VDWS. In fact, comparative disclosure studies tend generally to evaluate the differential impact of firm specific characteristics on information disclosure in two different legal systems (for example, common law and code law) or having different cultural values. However, few studies have analyzed this topic in countries having the same legal system and/or similar cultural values. The results illustrate a significant variation of VDWS practices across the two countries. The results show, also, that the majority of the identified determinants differ between these two countries in their significance and their sign. The principal results prove that firm size represents a positive common factor on the extent of VDWS in the two countries. The specific factors of British companies are: dispersion of ownership, performance, and the number of listing on foreign stock exchanges. Whereas those of New Zealand companies are bored independence and leverage level.
\end{abstract}

Keywords: Determinants, Voluntary Disclosure, Websites, United Kingdom, New Zealand.

\section{Introduction}

Listed companies have generally disclosed financial information to users by providing traditional paper-based disclosures. The widespread adoption of the internet has however, resulted in an increasing number of companies around the world using it to disclose financial information (Ali, 2010). Indeed, web-based reporting allows companies to benefit from cost saving and improve their financial reporting strategies (Almilia, 2009).

Bollen et al. (2008) suggest that the primary objective of Internet Financial Reporting (IFR) should be to provide investors with financial information to make capital allocation decisions. Therefore, investors and potential investors should easily be able to get information to make investment decisions. According to Hurtt et al. (2001) one of the benefits of providing information on the internet is that it improves access to potential investors. In addition, the internet can provide better and more effective ways of communicating financial and non-financial information (AgyeiMensah, 2012).

Disclosures in excess of those required by accounting standards or stock exchange listing requirement regulations, namely voluntary disclosures, have been an area of interest to researchers for many years (Agyei-Mensah, 2012). Companies continue to disclose voluntary information despite ever increasing mandatory requirements and so the motivation for such behaviour has been the focus of much attention (Watson et al., 2002).

All through this research, we will study Voluntary Information Disclosure on the Web-Sites (VDWS) of listed United Kingdom and New Zealand companies for several reasons. Indeed, most of the extant comparative research, focusing on this topic, uses the legal system to differentiate between countries in their sample in order to compare between two groups of countries (or more) that belong to different legal systems. Through such a comparison, researchers would generalise their results. Here, we can quote studies which essentially differentiates between common law countries and code law ones (Jaggi and Low, 2000; Hope, 2003; Paturel et al. 2006). Through this classification, researchers concluded that common law countries disclose more than code law ones, or further, that the firm specific determinants differ between the two groups of countries because of their different legal systems (Archambault and Archambault, 2003; Hope, 2003; Paturel et al. 2006).

However, research has shown that there can be a significant variation in voluntary disclosure within countries belonging to the same legal regime (Allam and lymer, 2003). In fact, these authors have focused on five developed countries (USA, UK, Canada, Australia, and Hong Kong). Their study show, amongst other things, that although the IFR level index of USA, UK and Canada (which belong to the same legal system: common law regime) are close, there is a significant variation across the three countries. "In other words, IFR practices are different between the three countries, not as appeared to be the case initially", Allam and Lymer (2003). However, these authors explore only the impact of firm size on IFR level and they do not study the differential impact of other firm specific characteristics on IFR level in these countries. In other words, they do not show if their firms' specific determinants differ from each other or not. Thus, it would be relevant to focus on studying the differential impact of some firm specific characteristics in a similar legal system on firms' VDWS. 
In fact, according to the classification of Salter and Doupnik (1992), the United Kingdom and New Zealand belong to the same legal system (the common law regime). In addition to the legal system, these two countries are culturally close. Indeed, New Zealand, an island country located in the southwestern Pacific Ocean, is a British colony for about 66 years. So, the culture of this small nation is largely inherited from British custom. Further, according to Hofstede model, both the United Kingdom and New Zealand are clustered together in the same group, because their scores on the four value dimensions are close, reflecting that they have similar cultural dimensions (Hofstede, 1983).

This paper tries to expand our understanding of the differential impact of some firm specific characteristics in a similar legal model and cultural values on firms' VDWS. It does so by comparing two countries from the common law model and having similar cultural dimensions.

The remainder of this paper is organized as follows. The first section presents the theoretical foundation that may explain the decision of VDWS. The research methodology is presented in the second section followed by the discussion of the results in the third section. Finally, in the fourth section conclusions are drawn and suggestions are made.

\section{Theoretical foundation and hypotheses}

This study proposes that VDWS should be viewed not only in terms of economic theories of disclosure (agency and signaling theories) but also in terms of innovation diffusion theory (Rogers, 1962).

According to Rogers (1962), innovation diffusion theory is concerned with the manner in which a new technological idea (an innovation) migrates from the creation to use (Hossain et al 2012). In this case, disclosure on web-sites is the innovation in question.

Rogers (1995, p.15-17) identified five critical attributes that greatly influence the rate of adoption (Aly, 2008; Hossain et al. 2012):

- Relative advantage: if an innovation has a higher relative advantage, it will be adopted more rapidly.

- Compatibility: if an innovation is perceived to be consistent with existing values, past experiences and needs of potential adopters, it will be easier to adopt.

- Complexity: new ideas that are simple to understand are adopted more rapidly than those which require the innovator to develop new skills and understandings.

- Trial-ability: new ideas that can be trialled represent less uncertainty to the individual who considering their adoption, since the individual can evaluate the ideas before deciding whether to adopt.

- Observability: this refers to the degree to which the results of an innovation can be seen by others. If the results of an innovation are observed easily, it will, if perceived a success, be adopted faster.

Therefore, according to the innovation diffusion theory, the rate of adoption of VDWS will depend upon how firms perceive the attributes summarized above.

The different foci of the economics-based and innovation diffusion theories suggest that they can supplement each other to produce a richer understanding of IFR practices (Xiao et al. 2004). We employed these theories to explain our findings in the UK and New Zealand.

Rather, following Hossain et al. (2012), we only used characteristics of the adopters (i,e, organizational variables) to determine factors currently influencing VDWS practices.

We, therefore, developed the following hypotheses based on previous literature and the explanation provided by these theories.

\subsection{Difference in VDWS practices between the UK and New Zealand}

In their study in five developed countries, Allam and Lymer (2003) show, amongst other things, that although the IFR level index of USA, UK and Canada (which belong to the same common law regime) are close, there are significant variations across the three countries. They argue that "IFR practices are different between the three countries not as appeared to be the case initially".

Thus, we test the following hypothesis:

$\mathrm{H} 1$ : VDWS practices are different across the UK and New Zealand.

\subsection{Explicative factors of voluntary disclosure on web- sites}

From the explanations suggested by the economics-based and innovation diffusion theories and studies relating to the determinants of VDWS, we identified the factors which could explain managers' decision to voluntarily disclose more information on the web-sites of their companies. These factors include: firm size, dispersion of ownership, board independence, performance, leverage and listing on foreign stock exchanges.

\subsubsection{Size}

According to Jensen and Meckling (1976), agency costs increase along with company size. The largest companies disclose more information than the smallest ones because they are ready to support the costs of this decision. Moreover, according to the signal theory, managers of large companies are more incited to proclaim the quality of their business to investors through voluntary disclosure. According to innovation diffusion theory, larger companies can better afford innovations and are more likely to have the necessary technological and personal resources (Flanagin, 2000; Abughazaleh et al. 2012).

Results from prior studies frequently confirm a positive association between company size and disclosure level. Among these studies, we can quote that of Marston and Polei (2004) in the German context, Haniffa and Rashid (2005) in the Malaysian context, Lopes and Rodrigues (2007) in the Portuguese context, Almilia (2009) in the Indonesian context and Turel (2010) in the Turkish context.

Generally, studies in common law countries also validate this result. For example, we can quote that of Oyelere et al. (2003) in New Zealand, Trabelsi et al. (2008) in Canada and Kelton and Yang (2008) in USA. However, the results of Allam and Lymer (2003) show a contradictory result and suggest that there is no relationship between the size of the companies and the IFR level in USA, UK, Canada (three countries from the common law model) and Hong Kong.

Because of this result, we choose to study company size and based on theories mentioned above, we formulate the following hypothesis:

H 2: VDWS is positively related to the company size.

\subsubsection{Dispersion of ownership}

Ownership structure may also be an important factor in voluntary web-based corporate disclosure. Indeed, according to agency theory, agency costs are significant in companies characterized by diffuse ownership. These costs can be reduced by a monitoring system which encourages managers to make their actions more transparent by voluntarily disclosing more information so as to reduce the divergences of interests.

Moreover, according to the signal theory, voluntary disclosure allows the reduction of information asymmetry between managers and shareholders. Consequently, it is likely that companies with a more dispersed ownership of shares will disclose more information on their corporate web-sites so as to reduce information asymmetry and provide their shareholders with the necessary information. 
In prior research studies, authors generally confirm a positive association between dispersion of ownership and IFR level in different countries such as Pirchegger and Wagenhofer (1999) in Austria, Chau and Gray (2002) in Hong Kong and Singapore, Oyelere et al. (2003) in New Zealand, Pervan (2006) in Croatia and Kelton and Yang (2008) in USA.

Based on all the above, we propose to test the influence of the dispersion of ownership on the VDWS by the following hypothesis:

H 3: VDWS is positively related to dispersion of ownership.

\subsubsection{Board independence}

The board of directors plays an important role in the control of managers' decisions, and particularly voluntary disclosure decision. Its effectiveness depends largely on its characteristics (composition, independence, etc).

In our study, we will be interested in board independence. Fama (1980) and Fama and Jensen (1983) consider that an effective board of directors must be composed of internal as well as outside members whose expertise, experience and independence make it possible to control management decisions. Indeed, they suggest that the effectiveness of the board of directors improves with the introduction of outside directors concerned about their reputation relating to the control of decisions in the job market. These decisions also relate to voluntary information disclosure. In addition, the agency theory suggests that a greater proportion of outside directors is more likely to minimize managerial opportunism and to reduce, consequently, the agency costs (Fama and Jensen, 1983).

Moreover, according to Kelton and Yang (2008), a significant percentage of independent directors reduce the probability of withholding decision information by managers. Chen and Jaggi (2000) confirm the existence of a positive relation between the level of information disclosure and board independence in the context of Hong Kong. In a subsequent study on the Malaysian context, Homayoun and Abdul Rahman (2010) show that the percentage of independent non-executive directors on board is positively significant with disclosure index of corporate governance on the internet. They add that a high percentage of independent directors on board enhances the control of managerial opportunism and reduces managers' chance of withholding information on corporate governance.

Therefore, the following hypothesis is suggested:

H 4: VDWS is positively related to board independence.

\subsubsection{Performance}

The signal theory suggests that managers of profitable companies are more willing to voluntarily disclose more information to improve the value of their firm by revealing good news. In addition, performance is a variable which was studied in several frameworks. Nevertheless, the empirical results are generally contradictory. For example, through their study of the determinants of voluntary web-based disclosure, Oyelere et al. (2003) did not find any significant relationship between performance and IFR in the New Zealand context. Other subsequent studies confirmed this result (Marston and Polei, 2004; Haniffa and Rashid, 2004; Leventis and Weetman, 2004; Barako et al., 2008).

On the other hand, Prabowo and Tambotoh (2005) found that performance is positively related to IFR among Indonesian manufacturing companies. They explained their result by the fact that profitable companies are more inclined to voluntarily disclose more details about their activities so as to attract potential investors or to be distinguished from other less profitable companies. This result was confirmed by Pervan (2006) on the Croatian companies and Ageyi-Mensah (2012) on Ghanaian ones.

Lang and Lundholm (1993) have advanced that managers of companies having negative information may disclose more information to improve the credibility of their published information or to reduce the likelihood of their legal liability. Belkaoui and Kahl
(1978) and Wallace et al. (1994) also found that company performance is inversely proportional to information disclosure.

Schadewlitz and Blevins (1998) expect a positive relationship between financial report disclosures and profitability. However, they found that company profitability seemed to reduce rather than increase the level of disclosure in reports. They provide two possible reasons for their finding. The first being that managers may consider that the existence of a company's good performance provides a sufficient signal of profitability and therefore find it unnecessary to disclose more information. The other reason provided was that the companies are not prepared to disclose additional information in its reports for fear of attracting new entrants in the industry. This could be a measure to protect their competitive position.

Taking into account the incongruent results of these studies, we did not predict the sign of this variable in accordance with the study of Leventis and Weetman (2004).

Hence, we propose the following hypothesis:

$\mathrm{H}$ 5: VDWS is related to performance.

\subsubsection{Leverage}

The presence of creditors in the capital structure accentuates agency conflicts (Jensen and Meckling, 1976). Actually, companies with more debt have greater agency cost due to the possibility of transferring wealth from debtholders to shareholders. Thus, highly leveraged companies are justified to disclose more information to satisfy the creditors' needs and to reduce the conflicts of interests. Several researchers studied the influence of leverage on voluntary disclosure. However, their results are dissimilar.

Indeed, Archambault and Archambault (2003) predicted in their study that highly leveraged companies will disclose more information in order to minimize agency costs. However, they did not find any relation between leverage and disclosure. This result is also confirmed by Almilia (2009), Barako et al. (2008) and AgeyiMensah (2012).

In addition, Haniffa and Rashid (2005) and Xiao et al. (2004) found that leverage level is positively related to the level of VDWS. In another direction, the results of Cormier et al. (2009) in the Canadian context showed that leverage is negatively related to performance disclosure. The subsequent study of Damaso and Lourenço (2011) on the British companies also confirmed that leverage is negatively related to the extent of disclosure on corporate web-sites.

Taking into account the disparate results of these studies, we did not predict the sign of this variable in accordance with the studies of Leventis and Weetman (2004), Prabowo and Tambotoh (2005) and Lopes and Rodrigues (2007).

Hence, we suggest the following hypothesis:

$\mathrm{H}$ 6: VDWS is related to leverage.

\subsubsection{Foreign stock exchange listings}

According to innovation diffusion theory, if the innovation has a higher relative advantage, it will be adopted more rapidly. Indeed, disclosing in web-sites (i,e, the innovation) allows to firms listed on foreign stock exchanges to, amongst other things, obtain investors throughout the world at a low cost (the relative advantage). So, if these firms will perceive this advantage, they will adopt the innovation more rapidly and therefore, they will increase their VDWS.

Further, inspired from Zarzeski's argument (1996), firms listed on foreign stock exchanges are adopting an international competitive strategy. So, in order to obtain foreign capital and enhance public image, they may choose to use VDWS at least as much as their competitors.

Several studies have analyzed the relation between listing on foreign financial markets and voluntary disclosure. Indeed, Cooke $(1989,1992)$ found that companies which are listed on foreign financial markets have an important level of voluntary disclosure compared to those which are listed on a national financial market. 
Moreover, the results of Adhikari and Tondkar' study (1992) announced a significant difference at the total level of the information disclosed between the companies which are listed on several foreign financial markets and those which are not. Similar results were obtained in New Zealand by Hossain et al. (1995).

Marston and Polei (2004) also found that German companies listed on international stock exchanges disseminate more information for investors on its web-site than those listed on domestic stock exchanges only. Other subsequent research validated this result. Among them, we can quote that of Lopes and Rodrigues (2007) in the Portuguese context.

Hence, we propose the following hypothesis:

$\mathrm{H}$ 7: VDWS is positively related to the number of foreign listing.

\section{Research methodology}

\subsection{Sample and data}

Our starting sample is formed of 100 British companies extracted from the FTSE 100 and 50 New Zealand companies forming NZX 50 market index in February 1, 2011. Within the framework of our study, we analyzed the contents of companies' web-sites studied over a one month period going from $1^{\text {st }}$ to 28 February, 2011. In order to improve internal and external validity of the measurement of the construct, the web-sites are visited twice to check the presence of each of the disclosure item. In line with the study of Turel (2010), the web-sites of our sample companies were re-examined at the end of February in order to ensure that no change was carried out on the already collected data.

It should be noted that the companies of our sample have different types of industry. There was no particular control on the industry effect because we assume, in accordance with the study of Haniffa and Rashid (2005), that VDWS is beneficial for all the companies regardless of their type of industry.

We eliminated, from our sample, a British company which did not yet have a web-site and three other companies, including two from New Zealand and one from the United Kingdom because of missing data. Hence, our final sample is composed of 98 British companies and 48 New Zealand. Table (1) summarizes the composition of the final samples of our study.

Table 1: Composition of Final Samples

\begin{tabular}{lll}
\multicolumn{2}{c}{ Table 1: Composition of Final Samples } \\
\hline Sample & $\begin{array}{l}\text { United King- } \\
\text { dom }\end{array}$ & $\begin{array}{l}\text { New Zea- } \\
\text { land }\end{array}$ \\
\hline $\begin{array}{l}\text { Total number of companies } \\
\begin{array}{l}\text { Disposal of companies without web- } \\
\text { sites }\end{array}\end{array}$ & 100 & 50 \\
$\begin{array}{l}\text { Disposal of companies with missing } \\
\text { data }\end{array}$ & $(1)$ & - \\
Final sample & $=98$ & $(2)$ \\
\hline
\end{tabular}

After having described the procedure for selecting our sample, we will present measurements of our variables.

\subsection{Definition and measurements of variables}

\subsubsection{Dependent variable (VDWS)}

VDWS index requires two different steps. First, we have to define what items (information contents) are going to compose VDWS index. Second, we have to specify the scoring method (a weighted or unweighted index).

Regarding the contents, given that the relevance of the score depends on the choice of items included in the disclosure index (Marston and Shrives, 1991; Trabelsi et al. 2008), our selection is based on items used in previous studies which have proposed a framework of web-based disclosure (Debreceny et al. 2001; Xiao et al. 2004). Moreover, since information demands vary from one user to another (Bonsón and Escboar, 2002), the disclosure lis was enlarged by adding items used in other previous studies which have took into account different types of user' profiles (Ettredge et al. 2002; Marston and Polei, 2004; Abdelsalem and Street, 2007; Kelton and Yang, 2008; Trabelsi et al. 2008, etc).

Furthermore, given that our objective is to measure voluntary information disclosed on web-site' companies, we eliminated all information mandated by financial regulatory authorities (Financial Services Authority in the United Kingdom and Financial Markets Authority in New Zealand) and we focused only on items referring to contents in web-sites.

Using these previous researches, a broad set of 51 items has been considered in this study including various types of information (stock exchange data, financial statements, projected information, social and environmental information, other non-financial information, etc.).

Regarding the scoring method, in the literature, two different approaches can be found: the weighted and the unweighted method (Cooke, 1989). Indeed, some researchers used the weighted method. We can quote that of Pirchegger and Wagenhofer (1999) and Marston and Polei (2004) which applied different weightings for each group of criteria based on analyst' opinions. This method demands the determination of the relative importance of items to different users. The use of the weighted method will reflect interests of particular information for users; hence, increasing the subjectivity in developing the disclosure indexes (Marston and Shrives, 1996). Another study concluded that there is no significant difference between the results based on weighted and unweighted disclosure indexes (Zarzeski, 1996).

The choice of the scoring method could depend on the focus of the research each self. In fact, if the research focuses on a particular user group, the weighted index is preferable, and if it focuses on all users the unweighted index is preferable (Alfaraih, 2009).

In consequence, since we suppose that the information provided is going to be employed by various types of users and we will not favour a particular set of users, we applied the most commonly used method from prior research which is to score items without weighting for relative importance (Cooke, 1989; Raffournier, 1995; Leventis and Weetman, 2004; Bonsón and Escobar, 2006; Lopes and Rodrigues, 2007, etc).

Thus, the procedure is dichotomous: if any information of the list appears on the web-site then it takes the value 1, if it does not, it takes the value 0 . The total score is the unweighted sum of the scores of each item. Then, in order to avoid penalizing a company which has some inapplicable items, we made a meticulous review of the web-site and, in some cases, the annual report in order to understand the activity of the company and specify items that are not applicable, in accordance with several studies (Cooke, 1989, Raffournier, 1995, Leventis and Weetman, 2004 and Lopes and Rodrigues, 2007). So, this score takes the shape of an index: a ratio which will take into account the number of information which the firm is likely to disclose.

Consequently, the VDWS index allotted to each company is: VDWS i = Total score of company i / Score of disclosure expected of the company $i$.

The disclosure index calculated enabled us to classify the companies of our sample in two groups: the first group consists of the companies which disclose more, and the second one consists of the companies which disclose less. This method of classification was used by Gelb and Zarowin (2002) and Arnone et al. (2010).

To be able to classify the companies in two groups, we used the average like indicator of classification in accordance with the study of Arnone et al. (2010). Indeed, any company which has a disclosure index higher than the average index of the sample will be classified in the first group which discloses more, and any company which has a disclosure index lower than the average index of the sample will be classified in the second group which discloses less. Thus, our dependent variable is a dummy variable which takes value 1 when the company belongs to the group which discloses more and 0 if it does not. The logistic model of regression is consequently adequate in our analysis. 


\subsubsection{Independent variables}

In order to control for agency costs, market forces and international dependence, we have defined these independent variables:

- Size (Ln.T): this variable is measured by the natural logarithm of the total assets. Several studies retained it as being a measurement of the size of the company (Prabowo and Tambotoh (2005), Trabelsi et al. (2008), Almilia (2009) and Homayoun and Abdul Rahman (2010).

Ln.T $=$ Log total assets

- Dispersion of ownership (DISP): this variable is measured by $(1$ - percentage of the shareholders holding more than $5 \%$ of the capital). This measurement was also used by Paturel et al. (2006).

$\mathrm{DISP}=1$ - percentage of the shareholders holding more than $5 \%$ of the capital.

- $\quad$ Board Independence (IND.B): it is the percentage of the independent directors in the board. This measurement was also used by Chen and Jaggi (2000), Xiao et al. (2004), Barako (2007), Kelton and Yang (2008), and Barako et al. (2008).

IND.B $=$ percentage of independent directors on the board

- Performance: it is a dummy variable which takes 1 if the net benefit of the year 2010 is higher than that of the year 2009 and 0 if it does not. This measurement was also used by Lang and Lundholm (1993) and Trabelsi et al. (2008).

Performance $(\mathrm{PERF})=$ dummy variable which takes 1 if the net benefit of the year 2010 is higher than that of year 2009 and 0 if it does not.

- Leverage: it is the total ratio of the debts on total assets. This measurement was also used by Eng and Mak (2003) Xiao et al. (2004) and Barako et al. (2008).

Leverage $(\mathrm{LEV})=$ total debts on total assets.

- $\quad$ Listing on foreign stock exchanges: it is the number of listing on foreign stock exchanges. This measurement was also used by Archambault and Archambault (2003).

Listing on foreign stock exchanges $(\mathrm{NMF})=$ the number of listing on foreign stock exchanges.

The empirical models that we test are as follows:

\begin{tabular}{lll} 
Model & United & $\mathrm{P}\left(\epsilon\right.$ group VDWS $\left.{ }^{+}\right) \alpha+\beta_{1}(\mathrm{Ln} . \mathrm{T})+\beta_{2}$ \\
$\mathrm{n}^{\circ} 1$ & Kingdom & $(\mathrm{DISP})+\beta_{3}(\mathrm{IND} . \mathrm{B})+\beta_{4}(\mathrm{PERF})+\beta_{5}(\mathrm{LEV})$ \\
Model & New Zea- & $+\beta_{6}(\mathrm{NMF})+\varepsilon$. \\
$\mathrm{n}^{\circ} 2$ & land & \\
\hline
\end{tabular}

\section{Empirical results}

In what follows, we will present the descriptive analyses of our variables, and then we will provide the principal results of our multivariate analyses.

\subsection{Descriptive analyses}

\subsubsection{Descriptive analysis of the dependent variable}

In order to know the extent of Voluntary Disclosure through WebSites, we will present the descriptive statistics of our dependent variable (VDWS) in table (2).

Table 2: Descriptive Statistics of the Dependent Variable (VDWS) VDWS index

\begin{tabular}{lll} 
VDWS index & & \\
\hline Origin & UK web-sites & NZ web-sites \\
Mean & 0.312 & 0.154 \\
Standard-deviation & 0.102 & 0.074 \\
Minimum & 0.080 & 0.021 \\
Maximum & 0.569 & 0.333 \\
\hline
\end{tabular}

Table (2) presents the distribution of the calculated index for British and New Zealand companies. It appears that the index varies significantly in the two countries. Through this table, we notice that there is a significant difference between British and New Zealand companies. The average index of British companies is of
0.312 (varies between 0.080 and 0.569 ) whereas that of New Zealand companies is of 0.154 (varies between 0.021 and 0.333 ). We can also note that British companies reveal more information than New Zealand companies. The descriptive statistics of the information revealed on web-sites are consigned in table (3) to know the extent of the VDWS.

Table 3: Descriptive Statistics of Disclosed Information on Corporate Web-Sites

\begin{tabular}{|c|c|c|}
\hline \multirow[t]{2}{*}{ List of disclosure index } & \multicolumn{2}{|c|}{$\begin{array}{l}\text { Percentage of dis- } \\
\text { closure }\end{array}$} \\
\hline & UK & $\mathrm{NZ}$ \\
\hline Stock exchange data & 75,773 & 44,533 \\
\hline 1. Current share price & 94,85 & 68,75 \\
\hline 2. Share price history & 88,66 & 52,08 \\
\hline 3. Share price changes compared to market index & 76,29 & 25,53 \\
\hline $\begin{array}{l}\text { 4. Changes from the last share price in percentage or } \\
\text { number }\end{array}$ & 92,78 & 43,75 \\
\hline $\begin{array}{l}\text { 5. Icon to calculate the change in the value of an invest- } \\
\text { ment over a period of time }\end{array}$ & 67,01 & 16,67 \\
\hline 6. link to the stock exchanges web-sites & 35,05 & 60,42 \\
\hline Summary of Financial Statements on corporate web-sites & 25,258 & 13,543 \\
\hline 7. Summary of financial data (at least, the last 5 years) & 28,87 & 35,42 \\
\hline 8. Current balance sheet & 25,77 & 6,25 \\
\hline 9. Current income statement & 25,77 & 4,17 \\
\hline 10. Current cash-flow statement & 20,62 & 8,33 \\
\hline Projected information & 7,215 & 1,042 \\
\hline 11. A projection of sales is provided & 8,25 & 0 \\
\hline 12. A projection of earnings per share is provided & 11,34 & 2,08 \\
\hline 13. A projection of future results is provided & 10,31 & 4,17 \\
\hline $\begin{array}{l}\text { 14. A Comparison of previous sales projections to actual } \\
\text { sales is provided }\end{array}$ & 3,09 & 0 \\
\hline $\begin{array}{l}\text { 15. A Comparison of previous earnings projections to } \\
\text { actual earnings is provided }\end{array}$ & 5,15 & 0 \\
\hline $\begin{array}{l}\text { 16. A Comparison of previous results projections to } \\
\text { actual results is provided }\end{array}$ & 5,15 & 0 \\
\hline Various other financial information & 34,811 & 16,508 \\
\hline 17. Dividend per share & 83,16 & 60,42 \\
\hline $\begin{array}{l}\text { 18. Icon to calculate the value of dividends over a period } \\
\text { of time }\end{array}$ & 29,9 & 2,08 \\
\hline 19. Dividend history & 76,29 & 62,5 \\
\hline 20. earnings per share & 55,67 & 22,92 \\
\hline 43. Analysts list & 51,55 & 18,75 \\
\hline 44. Reports of analysts & 12,37 & 4,17 \\
\hline 21. Shareholding structure & 34,02 & 22,92 \\
\hline 22. Debt structure & 12,37 & 2,08 \\
\hline 23. Evolution of debt structure & 9,28 & 2,08 \\
\hline 24. Expenditure on research and development & 16,44 & 0 \\
\hline $\begin{array}{l}\text { 25. Segmental financial information by indus- } \\
\text { try (revenues, expenses, profit, etc.) }\end{array}$ & 33,72 & 11,11 \\
\hline $\begin{array}{l}26 \text { Segmental financial information by geographical } \\
\text { area (revenues, expenses, profit, etc.) }\end{array}$ & 29,21 & 3,33 \\
\hline 27. Evolution of sales & 29,9 & 18,75 \\
\hline 28. Percentage of sales by geographic area & 13,48 & 0 \\
\hline Financial Analysis & 20,618 & 13,542 \\
\hline 29. Progression of turnover & 15,46 & 0 \\
\hline 30. Gearing ratios & 12,37 & 14,58 \\
\hline 31. Other ratios & 29,9 & 37,5 \\
\hline 32. Company's competitive position in its markets & 51,55 & 25 \\
\hline 33. Market share & 10,31 & 4,17 \\
\hline 34. Evolution of market share & 4,12 & 0 \\
\hline Social and environmental information & 37,492 & 11,805 \\
\hline 35. Number of employees & 71,13 & 31,25 \\
\hline 36. Data-t-on accidents & 46,74 & 8,33 \\
\hline 37. Expenditure on safety measures & 17,39 & 2,08 \\
\hline 38. Number of employees trained & 19,59 & 6,25 \\
\hline 39. Amount spent in training & 13,4 & 4,17 \\
\hline $\begin{array}{l}\text { 40. Information on environmental protection }(\mathrm{CO} 2 \text {, } \\
\text { water, electricity) }\end{array}$ & 56,7 & 18,75 \\
\hline Various other non-financial information & 14,810 & 7,287 \\
\hline 41. Geographical distribution of shareholders & 8,25 & 4,26 \\
\hline 42. Geographical distribution of employees & 20,22 & 6,45 \\
\hline 45. Organizational structure & 20,83 & 8,33 \\
\hline 46. Managers' remuneration & 6,19 & 4,17 \\
\hline 47. Information on R\&D types & 26,03 & 11,11 \\
\hline 48. Description of major customers & 13,54 & 6,25 \\
\hline 49. Description of major suppliers & 8,25 & 4,17 \\
\hline 50. Evolution of the number of customers & 8,33 & 10,42 \\
\hline 51. Evolution of the number of employees & 21,65 & 10,42 \\
\hline
\end{tabular}


The descriptive statistics presented in table (3) show a great inconsistency in the contents of the consulted websites. The comparison between the web-sites of the two countries shows that New Zealand companies disclose less information than British ones. However, this comparison also shows that New Zealand companies disclose more analytical information than those of the United Kingdom. Indeed, we find that the financial ratios (the gearing ratio and other financial ratios) are respectively present in $14,58 \%$ and $37,5 \%$ of New Zealand companies against $12,37 \%$ and 29 , $9 \%$ of British ones.

\subsubsection{Descriptive analysis of independent variables}

To identify the determinants of the VDWS for each country, we classified them in two groups per country. By comparing the disclosure index of each company with the average of the sample of each country $(0,312$ for the United Kingdom and 0,154 for New Zealand), we obtained a first group for the companies which disclose more information and a second group for those which disclose less.

The following table summarizes the classification of the two groups of each model.

Table 4: Classification of the Two Groups of Each Country

\begin{tabular}{|c|c|c|}
\hline & United King- & New Zea- \\
\hline Final sample & 90 & 47 \\
\hline Group VDWS ${ }^{+}$: companies with high & 54 & 22 \\
\hline Group VDWS ${ }^{-}$: companies with less & 36 & 25 \\
\hline
\end{tabular}

Table (4) shows that, in accordance with the study of Gelb and Zarowin (2002), the number of companies forming the first group is not equal to the number of those forming the second. Indeed, in model $n^{\circ} 1$ relating to the United Kingdom, the number of companies which disclose more is higher than the number of those which disclose less. The result of this classification implies that British companies which disclose more attach more importance to the VDWS than those which disclose less. As for model $n^{\circ} 2$ relating to New Zealand, the number of companies which disclose more is slightly lower than the number of those which disclose less.

The descriptive statistics of the two models (the United Kingdom and New Zealand) are presented in table (5) hereafter.

Table 6: Pearson Correlation and VIF

\begin{tabular}{|c|c|c|c|c|c|c|c|c|}
\hline \multirow{8}{*}{$\begin{array}{l}\text { Model } \mathrm{n}^{\circ} 1 \\
\text { (United Kingdom) }\end{array}$} & & & & & & & & \\
\hline & & Ln.T & DISP & IND.B & PERF & LEV & NMF & VIF \\
\hline & Ln.T & 1 & -0.024 & 0.177 & 0.027 & $0.454^{* *}$ & $0.532^{* *}$ & 1.971 \\
\hline & DISP & & 1 & -0.085 & -0.182 & $-0.310^{* *}$ & -0.041 & 1.165 \\
\hline & IND.B & & & 1 & 0.003 & $0.233^{*}$ & 0.120 & 1.049 \\
\hline & PERF & & & & 1 & 0.170 & -0.034 & 1.095 \\
\hline & LEV & & & & & 1 & $0.247^{*}$ & 1.718 \\
\hline & NMF & & & & & & 1 & 1.427 \\
\hline \multirow{7}{*}{$\begin{array}{l}\text { Model n }{ }^{\circ} 2 \\
\text { (New Zealand) }\end{array}$} & & Ln.T & DISP & IND.B & PERF & LEV & NMF & VIF \\
\hline & Ln.T & 1 & 0.100 & $0.386^{* *}$ & 0.036 & $0.717^{* *}$ & $0.638^{* *}$ & 2.682 \\
\hline & DISP & & 1 & -0.169 & -0.265 & -0.089 & -0.007 & 1.310 \\
\hline & IND.B & & & 1 & -0.021 & $0.357^{*}$ & $0.460^{* *}$ & 1.363 \\
\hline & PERF & & & & 1 & 0.130 & -0.085 & 1.161 \\
\hline & LEV & & & & & 1 & $0.395^{* *}$ & 1.959 \\
\hline & NMF & & & & & & 1 & 1.725 \\
\hline
\end{tabular}

Correlation is significant at the 0.05 level (2-tailed).

From the tables (6), it appears that all correlation coefficients are below 0.8 , which is the point at which we begin to have a serious problem of multicollinearity (Kennedy, 1985 Lewis-Beck, 1991). As a rule of thumb a VIF in excess of 5 is considered an indication of harmful multicollinearity (Zikmund et al., 2010). All the VIF are less than 5 and we note that the highest VIF is equal to 1.971 for the UK and 2.682 for New Zealand. Therefore, we can conclude that there is no multicollinearity problem.

After confirming the absence of multicollinearity between our explanatory variables, the logistic regression is carried out to examine to what extent the six independent variables explain the high or low Voluntary Disclosure level on Web-Sites.
Table 5: Descriptive analyses of the models $n^{\circ} 1$ and $n^{\circ} 2$ for the two countries (UK - NZ)

\begin{tabular}{|c|c|c|c|c|c|}
\hline Variable & Country & Group & $\mathrm{N}$ & Mean & Standard-deviation \\
\hline \multirow{4}{*}{ Ln.T } & \multirow{2}{*}{ UK } & VDWS + & 54 & 4.419 & 0.756 \\
\hline & & VDWS - & 36 & 3.844 & 0.593 \\
\hline & \multirow{2}{*}{$\mathrm{NZ}$} & VDWS + & 22 & 3.625 & 0.933 \\
\hline & & VDWS - & 25 & 2.718 & 0.455 \\
\hline \multirow{4}{*}{ DISP } & \multirow{2}{*}{ UK } & VDWS + & 54 & 0.818 & 0.149 \\
\hline & & VDWS - & 36 & 0.737 & 0.235 \\
\hline & \multirow{2}{*}{ NZ } & VDWS + & 22 & 0.546 & 0.222 \\
\hline & & VDWS - & 25 & 0.596 & 0.210 \\
\hline \multirow{4}{*}{ IND.B } & \multirow{2}{*}{ UK } & VDWS + & 54 & 0.592 & 0.117 \\
\hline & & VDWS - & 36 & 0.612 & 0.130 \\
\hline & \multirow{2}{*}{ NZ } & VDWS + & 22 & 0.722 & 0.163 \\
\hline & & VDWS - & 25 & 0.597 & 0.205 \\
\hline \multirow{4}{*}{ PERF } & \multirow{2}{*}{ UK } & VDWS + & 54 & 0.70 & 0.461 \\
\hline & & VDWS - & 36 & 0.81 & 0.401 \\
\hline & \multirow{2}{*}{$\mathrm{NZ}$} & VDWS + & 22 & 0.59 & 0.503 \\
\hline & & VDWS - & 25 & 0.68 & 0.476 \\
\hline \multirow{4}{*}{ LEV } & \multirow{2}{*}{ UK } & VDWS + & 54 & 0.662 & 0.196 \\
\hline & & VDWS - & 36 & 0.560 & 0.268 \\
\hline & \multirow{2}{*}{$\mathrm{NZ}$} & VDWS + & 22 & 0.533 & 0.208 \\
\hline & & VDWS - & 25 & 0.484 & 0.145 \\
\hline \multirow{4}{*}{ NMF } & \multirow{2}{*}{ UK } & VDWS + & 54 & 1 & 0.971 \\
\hline & & VDWS - & 36 & 0.22 & 0.422 \\
\hline & \multirow{2}{*}{$\mathrm{NZ}$} & VDWS + & 22 & 0.77 & 0.685 \\
\hline & & VDWS - & 25 & 0.4 & 0.577 \\
\hline
\end{tabular}

\subsubsection{Correlation analysis}

The application of the logistic regression requires the absence of multicollinearity between independent variables. It is therefore important to ensure that excessive collinearity between the independent variables will not affect the interpretation of results. To identify potential problems of multicollinearity between the independent variables, we have established a correlation matrix. We also calculated the Variable Inflation Factor (VIF) which also tests the presence of collinearity between the explanatory variables. The results of these tests are presented in table (6) below.

\subsection{Multivariate analysis and discussion}

In this section, we will first present the empirical results relating to the main hypothesis of our research. Next, we will present the results of our empirical model.

\subsubsection{Analysis of results relating to the main hypothesis}

Our main hypothesis to be tested is that VDWS practices are different across the UK and New Zealand. To test this hypothesis, we applied a further test Chi Square $\left(\chi^{2}\right)$ to examine whether or not the Voluntary Disclosure level on Web-Sites across the two countries is different although having several similarities as mentioned earlier.

The results are shown in Table (7). 
Table 7: Test Results Chi Square $\left(X^{2}\right)$ for the UK and New Zealand

\begin{tabular}{llllll}
\hline Variable & Group & $\begin{array}{l}\text { Number of } \\
\text { companies }\end{array}$ & Mean & $\begin{array}{l}\text { Standard- } \\
\text { deviation }\end{array}$ & $\begin{array}{l}\text { Test Chi } \\
\text { square }\left(\chi^{2}\right)\end{array}$ \\
\hline \multirow{4}{*}{ Country } & VDWS & 69 & 0.970 & 0.168 & $\begin{array}{l}\chi^{2}= \\
16.457 * * *\end{array}$ \\
& + & & & & $P=(0.000)$
\end{tabular}

The results shown in table (7) suggest a significant variation across the UK and New Zealand. In other words, VDWS practices are different between the two countries. So, H1, which states that VDWS practices are different across the UK and New Zealand, is supported by the results.

To better understand this result, we will deepen our research by a multivariate analysis in order to release the differential impact of the factors influencing VDWS choices.

\subsubsection{Logistical regression analysis}

The logistic analysis is conditioned neither by the normal distribution of error terms, nor by the assumption of homoscedasticity. It does not require the linearity between the dependent variable and the independent variables.

Moreover, the logistical regression analysis is very influenced by outliers. Consequently, before starting the descriptive analysis, we carried out an estimate of the values which could skew the logistical regression model. We eliminated from our sample the extreme observations whose standardized residues exceed the 2 standard deviations on both sides average which is the usual level of elimination. After these eliminations, our two final samples are composed of 90 British companies and 47 New Zealand companies. Thus, the results of the two empirical models are summarized in table (8) hereafter.

Table 8: Results Of Logistic Regression: Group $\mathrm{VDWS}^{+} /$VDWS

\begin{tabular}{|c|c|c|c|c|c|c|}
\hline & \multicolumn{6}{|c|}{$\mathrm{P}\left(\epsilon\right.$ group VDWS $\left.{ }^{+}\right)=\alpha+\beta_{1}($ Ln.T $)+\beta_{2}(\mathrm{DISP})+\beta_{3}(\mathrm{IND} . \mathrm{B})+\beta_{4}(\mathrm{PERF})+\beta_{5}(\mathrm{LEV})+\beta_{6}(\mathrm{NMF})+\varepsilon$} \\
\hline Variables & Predicted Sign & Coef $\beta$ & Significant (p) & Predicted Sign & Coef $\beta$ & Significant (p) \\
\hline Ln.T & + & 0.908 & $0.058 *$ & + & 6.386 & $0.002 * * *$ \\
\hline DISP & + & 3.460 & $0.040 * *$ & + & 2.399 & 0.323 \\
\hline IND.B & + & -6.208 & $0.031 * *$ & + & 4.699 & $0.091 *$ \\
\hline PERF & $+/-$ & -1.295 & $0.072 *$ & $+/-$ & -1.074 & 0.384 \\
\hline LEV & $+/-$ & 1.141 & 0.429 & $+/-$ & -14.080 & $0.012 * *$ \\
\hline NMF & + & 1.995 & $0.001 * * *$ & + & -1.777 & $0.071^{*}$ \\
\hline
\end{tabular}

In what follows, we will show initially, the results found for model $n^{\circ} 1$ relating to the United Kingdom and, afterwards, the results found for model $n^{\circ} 2$ relating to New Zealand. Finally, we will present a comparative analysis of the determinants between the two countries.

\subsubsection{Results of model $n^{\circ} 1$}

From table (8), we notice that the tested model is overall significant. Indeed, the test Chi square $\left(\chi^{2}\right)$ for the adjustment of the model is of 40.345 and is significant at $p=0.000$. Nagelkerke's $R^{2}$ indicates that $48,8 \%$ of the probability of disclosing more information on websites is explained by the six variables integrated in the model.

$\mathrm{H} 2$, which states that size is positively related to web-based disclosure, is supported by the results. This finding is in consistent by economic-based and innovation diffusion theories. It is also widely evidenced in the literature on disclosure (Ashbaugh et al., 1999; Pirchegger and Wagenhofer, 1999; Craven and Marston, 1999; Ettredge et al., 2002; Oyelere at al., 2003; Marston and Polei, 2004; Haniffa and Rashid, 2005; Prabowo and Tambotoh, 2005; Lopes and Rodrigues, 2007; Barako at al., 2008).

$\mathrm{H} 3$, which states that dispersion of ownership is positively related to disclosure on web-sites, is supported by the results. This is consistent with the economic-based theories and the study of Oyelere at al. (2003) in the New Zealand context and that of Abughazalah et al. (2012) in Jordanian one.

The coefficient of performance is statistically significant in this model providing, as such, support for $\mathrm{H} 5$ which states that performance is related to disclosure on web-sites. Contrary to the study of Prabowo and Tambotoh (2005) on Indonesia and that of Ageyi-Mensah (2012) on Ghana, the coefficient relative to this variable is negative. However, this finding confirms those of Wallace and Naser (1995), Lang and Lundholm (1993) and Schadewlitz and Blevins (1998).

$\mathrm{H} 7$, which states that the number of listings on foreign stock exchanges is positively related to disclosure on web-sites, is supported by the results. This result is consistent with innovation diffusion theory and the study of Xiao et al. (2004) on Chinese companies, Marston and Polei (2004) on German companies, Lopes and Rodrigues (2007) on Portuguese companies and Trabelsi et al. (2008) on Canadian companies.

The board independence variable is statistically significant. However, contrary to the sign expected, the coefficient is negative. Thus, H4 is not supported. This finding is in contrast to the study of Homayoun and Abdul Rahman (2010) on the Malaysian companies.

Against our expectations, the results do not verify the influence of leverage on web-sites' disclosure. Indeed, the leverage variable is not statistically significant. So, H6 is not supported. Consequently, the level of debt did not influence the disclosure level on web-sites in the United Kingdom model.

Thus, for this model, the multivariate analysis shows a positive and significant influence of firm size, dispersion of ownership, and number of listing on foreign stock exchanges on the decision to disclose more information on web-sites. It also shows a negative and significant influence of the company performance on the disclosure level on web-sites. In addition, the board independence variable, contrary to the expected sign, had a negative effect. As for the leverage variable, it did not have any significant effect on the decision to disclose more information on web-sites.

In other words, British companies which voluntarily disclose more information on their web-sites are probably larger, less profitable, have a more dispersed structure ownership, listed on more foreign stock exchanges, and have less important proportion of independent administrators than those which disclose less.

In what follows, we will present model $n^{\circ} 2$ relating to New Zealand.

\subsubsection{Results of model $n^{\circ} 2$}

From table (8), we notice that the tested model is overall significant. Indeed, the test Chi square $\left(\chi^{2}\right)$ for the adjustment of the model is of 32.866 and is significant at $p=0.000$. Nagelkerke's $R^{2}$ indicates that $67,2 \%$ of the probability of disclosing more information on web-sites is explained by the six variables integrated in the model. 
$\mathrm{H} 2$, which states that size is positively related to web-based disclosure, is supported by the results. This is consistent with our findings on British companies and with the majority of the previous studies.

$\mathrm{H} 4$, which states that board independence is positively related to web-based disclosure, is supported by the results. This finding is consistent with agency theory and the study of Xiao et al. (2004) in the Chinese context, that of Kelton and Yang (2008) in the American context and that of Homayoun and Abdul Rahman (2010) in the Malaysian context.

H6, which states that leverage is related to disclosure on web-sites, is supported by the results. Indeed, the leverage variable is statistically significant. Moreover, contrary to the study of Haniffa and Rashid (2005) in Malaysia and that of Ageyi-Mensah (2012) on Ghana, the coefficient is negative in accordance with the study of Hope (2003) on the Anglo-Saxon countries, that of Cormier et al (2009) in the Canadian context and that of Damaso and Lourenço (2011) on the British companies.

The variable number of listing on foreign stock exchanges is statistically significant. However, contrary to our expectations and to the study of Lopes and Rodrigues (2007) in the Portuguese context, the sign is negative. Thus, H7 is not supported.

Neither the dispersion of ownership nor the performance proves to be related to web-based disclosures. Thus, H3 and H5 are not supported by the results. Consequently, these variables do not influence the decision of voluntary web-based disclosures in New Zealand.

Thus, for model $\mathrm{n}^{\circ} 2$ relating to New Zealand, the multivariate analysis shows a significant and positive influence of firm size and board independence on the decision to disclose more information on web-sites. It also shows a negative and significant influence of leverage on VDWS. In addition, the analysis shows that the number of listing on foreign stock exchanges is statistically significant but is contrary to the expected sign. On the other hand, the dispersion of ownership and the performance variables do not have significant effects on the decision to disclose more information on web-sites.

In other words, New Zealand companies which voluntary disclose more information on their websites are probably larger, have a more independent board of directors, are more indebted and have a lower number of listing on foreign stock exchanges than those which disclose less.

\subsubsection{Analysis and discussion}

In what follows, we will identify the common factors between the two countries and the factors specific to each country.

\subsubsection{Common factor between the two countries}

The size is a significant variable for the two countries $(p=0.059$ for the United Kingdom and $p=0.002$ for New Zealand). This result is consistent with economic-based and innovation diffusion theories and several previous studies which show the positive influence of this variable on voluntary disclosure via web-sites (Ashbaugh et al., 1999; Pirchegger and Wagenhofer, 1999; Craven and Marston, 1999; Ettredge et al., 2002; Oyelere et al., 2003; Marston and Polei, 2004; Haniffa and Rashid, 2005; Lopes and Rodrigues, 2007; Barako et al., 2008). We notice that our result is inconsistent with Pervan (2006) on Slovenia, Ageyi-Mensah (2012) on Ghana and Allam and Lymer (2003) on USA, UK, Canada and Hong Kong which do not find a significant and positive relation between firm size and the VDWS.

Indeed, this result shows that larger companies may have the resources to produce more disclosures in order to reduce agency costs in consistent with the agency theory or that managers of larger ones may disclose more to prove the quality of their business to investors in consistent with the signal theory. This result could also prove that larger companies are more able to adopt innovations because they are more likely to have the necessary technological and personal resources in consistent with innovation diffusion theory.
Having size as a common factor may suggest that there is no differential impact of firm size on VDWS in the UK and New Zealand.

\subsubsection{Specific factors of each country}

Though having a strong relationship since the colonial past and belonging to the same Anglo-Saxon model, the companies of the UK and New Zealand hold different factors that incite them to voluntarily disclose more information on their web-sites. Indeed, except for the size as a common factor between the two countries, there is a differential impact of dispersion of ownership, performance, leverage, board independence and number of listing on foreign stock exchanges on VDWS in the UK and New Zealand.

Our findings can be classified in two types of results: in the first one, we find the variables which are significant in a country and not significant in the other. In the second one, we find the variables which are significant in both countries but with opposite signs.

Concerning the first type of results, our findings show that there are three variables which are significant in a country and not significant in the other. Indeed, we find that dispersion of ownership positively influences VDWS in the UK and has no significant effect in New Zealand. So, British companies which have a diffuse ownership would be more motivated to disclose more information on web-sites. It could be explained by the fact that the structure of ownership in British companies is more diffused than New Zealand ones. So, British companies may have a greater number of shareholders who would ask for more information on the websites. This result could also suggest that increased VDWS may be seen as a suitable response to reduce potential conflict and information asymmetry between shareholders and management in consistent with the agency and signal theory.

Further, we find that performance negatively influences VDWS in the UK and has no significant effect in New Zealand. In consequence, managers of least profitable British companies are incited to voluntarily disclose more information on their web-sites. It is possible that British companies try to improve the credibility of the information published on companies' web-sites or to minimize the likelihood of their legal liability because of insufficient or bad synchronization of information. This result could also mean that more profitable British companies are not incited to voluntarily disclose more information on their web-sites. In reference to the study of Schadewlitz and Blevins (1998), this finding could be explained by two possible reasons. The first one is that managers may think that the existence of a company's good performance provides a good signal of profitability. So, it is unnecessary to disclose more information. The second reason is that the more profitable companies would not disclose additional information in their web-sites for fear of attracting new entrants in the industry. This could be a suitable measure to protect competitive position. In addition, we find that leverage negatively influences VDWS in New Zealand and has no significant effect in the UK. So, VDWS in New Zealand decreases with leverage. In other words, the most indebted companies are not motivated to voluntarily disclose more information on their web-sites. In reference to the study of Zarzeski (1996), this finding is probably due to the fact that creditors can obtain private information and therefore, managers of New Zealand companies are not motivated to provide more information on their web-sites to reassure them.

Concerning the second type of results, we find that number of listing on foreign stock exchanges and independence of the board are significant in both of the two countries but with opposite signs. Indeed, number of listing on foreign stock exchanges positively influences VDWS in the UK while it negatively influences VDWS in New Zealand. This means that British companies which are listed on many foreign stock exchanges disclose more information on their web-sites. So, it is possible that since they operate in an international market, they are adopting an international competitive strategy. So, in consistent with Zarzeski's argument (1996), competitive pressures will push firms to disclose at least as much 
as their competitors. It is also possible that they would use this innovation because it can better afford to have a world visibility and therefore, to obtain foreign investors at a relatively low cost in consistent with innovation diffusion theory. In the other hand, this result means that New Zealand companies listed on the national stock exchange disclose more information on their websites. So, they probably try to reassure their local investors, which will, accordingly, improve their reputation in the market. This result also means that New Zealand companies listed on more foreign stock exchanges do not adopt VDWS. So, probably, for fearing of losing the competitive advantage or in order to protect themselves from arriving new competitors, they would not provide additional information on their web-sites.

Moreover, board independence positively influences VDWS in New Zealand while it negatively influences VDWS in the UK. This means that New Zealand companies which have a more independent board of directors disclose voluntarily more information on their web-sites. So, in New Zealand companies, a greater proportion of outside directors is probably used to minimize managerial opportunism and agency costs, in consistent with agency theory. It is also possible that independent directors are worried about their reputation on the job market, that is why they would try to offer more transparent information by the way of VDWS. Whereas, this result means that British companies which have a more dependent board of directors communicate more VDWS Such a result could be explained by the fact that managers seek to maintain their place in the company or that British companies probably resort to other means to control managers' opportunism. Since our findings show that the UK and New Zealand present different factors, both in significance and sign, which influence firms' VDWS choices, we can conclude that there is a differential impact of some firms' specific characteristics on VDWS even between countries having similar cultural values and legal systems.

\section{Conclusion}

The objective of our research is double: first, we tried to evaluate and compare the current level of VDWS practices of the UK and its former colony, New Zealand. Accordingly, we developed a disclosure index for each of the two countries based on prior literature. Second, we examined whether or not the Voluntary Disclosure level on Web-Sites across the two countries is different and we studied the determinants of the VDWS of the two countries using two independent samples to identify the common factors between them and the specific factors relative to each one.

To reach our primary goal, we examined the web-sites of 98 British companies belonging to index FTSE 100 and of 48 New Zealand companies belonging to index NZX 50, and we calculated a VDWS index for each one. The achievement of this stage enabled us to notice the important variation of the indices within each country. The average index of British companies is of 0,312 whereas that of New Zealand companies is of 0,154 . We also noticed a great inconsistency in the contents of the consulted websites. Indeed, as a whole, the stock exchange data are the mostly present information on the web-sites of the two countries whereas forecasting information is almost inexistent on the web-sites of New Zealand companies and slightly disclosed on the web-sites of British ones. Moreover, the comparison between the web-sites of the two countries suggests that the level of VDWS of New Zealand companies is rather low compared to that of British ones. However, this comparison suggests, also, that New Zealand companies disclose more analytical information than those of the United Kingdom.

To achieve our second goal, our analysis focused on a final sample of 90 British companies and 47 New Zealand companies. The results suggest a significant variation across the UK and New Zealand. In other words, VDWS practices are different between the two countries. Moreover, the two tested models are largely significant. The results of our research show that firm size has a significant influence on the level of VDWS in the two countries. Having size as a common factor may suggest that there is no differential impact of firm size on VDWS in the UK and New Zealand.

Despite their similar cultural values and legal systems, British and New Zealand companies hold different factors that incite them to voluntarily disclose more information on their web-sites. Except for the size as a common factor between the two countries, there is a differential impact of dispersion of ownership, performance, leverage, board independence and number of listing on foreign stock exchanges on VDWS in the UK and New Zealand.

Indeed, our findings show that there are three variables which are significant in a country and not significant in the other: dispersion of ownership, performance and leverage. In fact, we find that dispersion of ownership positively influences VDWS in the UK and has no significant effect in New Zealand. Further, performance negatively influences VDWS in the UK and has no significant effect in New Zealand. Finally, leverage negatively influences VDWS in New Zealand and has no significant effect in the UK. We also find variables which are significant in both countries but with opposite signs: number of listing on foreign stock exchanges and independence of the board. In fact, number of listing on foreign stock exchanges positively influences VDWS in the UK while it negatively influences VDWS in New Zealand. Moreover, board independence positively influences VDWS in New Zealand while it negatively influences VDWS in the UK.

This study demonstrates the usefulness of theoretical approaches in explaining VDWS. It tries to expand our understanding of the differential impact of some firm specific characteristics in a similar legal systems and cultural values on firms' VDWS.

However, this study presents some limitations. First, it covered only the web-sites of the biggest British and New Zealand companies. So, our results may not be generalized to firms trading on other stock exchanges. The selection of the companies could be expanded to include small and medium sized companies. Then, although we included several variables associated with VDWS, we may have failed to identify all potentially correlated variables. Future research might extend the scope of this study by involving comparative studies with other countries. Then, a thorough research could be undertaken by integrating institutional variables, in addition to the economic and financial ones. We propose, also, to undertake a multi-support study. Indeed, it could bring further explanations of this practice and the importance of the factors which influence this decision. It could be also interesting to use other measurements for the studied factors.

\section{References}

[1] AbuGhazaleh, N.M.; Qasim, A.; Roberts, C. (2012), "The determinants of web-based investor relations activities by companies operating in emerging economies : the case of Jordan", The journal of applied business research, Vol. 28(2), p. 209-225;

[2] Abdelsalam, O.H. and Street, D.L. (2007), "Corporate governance and the timeliness of corporate internet reporting by U.K. listed companies". Journal of International Accounting, Auditing and Taxation, Vol. 16, pp.111-130; http://dx.doi.org/10.1016/j.intaccaudtax.2007.06.001.

[3] Adhikari, A. and Tondkar, R. H. (1992), "Environmental factors influencing accounting disclosure requirements of global stock exchanges", Journal of International Financial Management and Accounting, Vol. 4 (2), pp. 75-105; http://dx.doi.org/10.1111/j.1467646X.1992.tb00024.x.

[4] Agyei-Mensah Ben K. (2012), "Corporate financial reporting: Firm characteristics and the use of internet as a medium of communication by listed firms in Ghana", African Journal of Business Management, Vol. 6(6), pp.2299-2309;

[5] Al faraih, M. (2009), "Compliance with International financial Reporting Standards (IFRS) and the value Relevance of Accounting information in Emerging Stock Market: Evidence from Kuwait" .Thesis;

[6] Allam, A., \& Lymer, A. (2003), "Developments in Internet Financial reporting: Review and Analysis Across Five Developed Countries", 
The International Journal of Digitial Accounting Research, Vol.3(6), pp. 165-199;

[7] Almilia, L.S., (2009), "Determining factors of internet financial reporting in Indonesia", Accounting and taxation, Vol. 1(1);

[8] Ali, I. (2010). "Internet financial reporting: A review of the literature and further evidence from New Zealand". In Proceedings of the Auckland Regional Accounting 2010 Annual Conference, Auckland, New Zealand;

[9] Archambault J. J. and Archambault M. E., (2003), "A multinationa test of determinants of corporate disclosure", The International Journal of Accounting, Vol. 38, pp. 173-194 http://dx.doi.org/10.1016/S0020-7063(03)00021-9.

[10]Arnone, L., Colot, O., Croquet, M., Geerts, A. and Pozniak, L. (2010), "Internet comme vecteur de communication financière : une analyse des sociétés du Marché Libre", La Revue des Sciences de Gestion, Di rection et Gestion, $\mathrm{n}^{\circ} 242$, p. 49 ;

[11]Ashbaugh J., Johnstone K.M. and Warfield, T.D., (1999), “Corporate reporting on the Internet", Accounting Horizons, Vol. 13(3), pp. 241 257; http://dx.doi.org/10.2308/acch.1999.13.3.241.

[12]Barako. D.G., (2007), "Determinants of voluntary disclosures in Kenyan companies annual reports", African Journal of Business Management, Vol. 1(5) pp. 113-128;

[13]Barako, D.G., Tower. R. and Tower G. (2008), "Web communication: An Indonesian perspective", African Journal of Business Manage ment, Vol. 2 (3), pp. 053-058;

[14]Belkaoui A. , Kahl A. (1978): "Corporate financial disclosure in Canada", Vancouver: Research Monograph of Canadian Certified General Accountants Association, No. 1;

[15]Bollen, L., Hassink, H., Lange, R., \& Buijl, S. (2008). "Best Practices in Managing Investor Relations Websites: Directions for Future Research", Journal of Information Systems, Vol. 22 (2), pp. 171-194 http://dx.doi.org/10.2308/jis.2008.22.2.171

[16]Bonson, E. and Escobar, T. (2002), "A Survey on voluntary disclosure on the internet: Empirical evidence from 300 European Union companies", The International Journal of Digital Accounting Research, Vol 2(1), pp. 27-51;

[17]Bonson, E. and Escobar, T. (2006), "Digital reporting in Eastern Europe: An empirical study", International Journal of Accounting Information Systems, Vol. 7, pp. 299-318; http://dx.doi.org/10.1016/j.accinf.2006.09.001

[18]Chau, G.K. and Gray, S.J. (2002), "Ownership structure and corporate voluntary disclosure in Hong Kong and Singapore", The International Journal of Accounting, Vol. 37, pp. 247-265; http://dx.doi.org/10.1016/S0020-7063 (02)00153-X

[19]Chen, C. J. and B. Jaggi. (2000), “Association between independent non-executive directors, family control and financial disclosures in Hong Kong", Journal of Accounting and Public Policy, Vol. 19 (4-5) pp. 285-310; http://dx.doi.org/10.1016/S0278-4254 (00)00015-6.

[20]Cooke, T. (1989), "Disclosure in the corporate annual reports of Swedish companies", Accounting and Business Research, Vol. 19 (74), pp. 113-124; http://dx.doi.org/10.1080/00014788.1989.9728841.

[21]Cooke, T. (1992), "The impact of size, stock market listing and industry type on disclosure in the annual reports of Japanese listed corporations", Accounting and Business Research, Vol. 22 (87), pp. 229-237; http://dx.doi.org/10.1080/00014788.1992.9729440.

[22]Cormier, D., Ledoux, M. and Magnam, M.(2009), "The use of websites as a disclosure platform for corporate performance", Interna tional Journal of Accounting Information Systems, Vol 10 (1), pp.124; http://dx.doi.org/10.1016/j.accinf.2008.04.002.

[23]Craven B. and Marston C., (1999), "Financial reporting on the Internet by leading UK companies", The European Accounting Review, Vol 8, pp. 335-350; http://dx.doi.org/10.1080/096381899336069.

[24]Damaso G, and Lourenco I (2011), "Internet financial reporting: environmental impact companies other determinants", International Conference on Enterprise Systems, Accenting and Logistics, Vol. 8, pp $331-334$

[25]Debreceny, R., Gray, G.L. and Mockk, T.J. (2001), Financial reporting websites: what users want in terms of form and content", The in ternational journal of digital accounting research, Vol.1 (1), pp 1-26;

[26]DiMaggio P.J. and Powell W.W. (1983), "The Iron Cage Revisited: Institutional Isomorphism and Collective Rationality in Organizationa Fields", American Sociological Review, Vol 48, pp. 147-160; http://dx.doi.org/10.2307/2095101.

[27]Eng, L. L. and Y. T. Mak. (2003), "Corporate governance and voluntary disclosure", Journal of Accounting and Public Policy, Vol. 22 pp. 325-45; http://dx.doi.org/10.1016/S0278-4254 (03)00037-1.

[28]Ettredge M., Richardson V.J. and Scholz S. (2002), "Dissemination of information for investors at corporate Web sites", Journal of Account ing and Public Policy, Vol. 21, pp. 357-369; http://dx.doi.org/10.1016/S0278-4254 (02)00066-2.
[29]Fama, E. F. (1980), "Agency Problems and the Theory of the Firm", Journal of Political Economy, Vol. 88 (2); http://dx.doi.org/10.1086/260866.

[30]Fama, E. F. and M. C. Jensen. (1983), "Separation of Ownership and Control", Journal of Law and Economics, Vol. 26; http://dx.doi.org/10.1086/467037.

[31]Gelb D.S. and Zarowin P. (2002), "Corporate Disclosure Policy and the Informativeness of Stock Prices", Review of Accounting Studies, Vol. 7 (1), p 33; http://dx.doi.org/10.1023/A:1017927530007.

[32]Haniffa, M.H. and Ab. Rashid, H. (2005), "The Determinants of Voluntary Disclosures in Malaysia: The Case of Internet Financial Reporting", UNITAR E-Journal, Vol. 2(1), pp. 22-42;

[33] Hofstede, G. (1983), "Dimensions of national cultures in fifty countries and three regions", In Derogowski, J. B., Dziuraweic, S. and Annis, R., eds, Expiscations in Cross-Cultural Psychology, Lisse, the Netherlands: Swets and Zeitlinger;

[34]Hope, O-K. (2003), "Firm-level disclosures and the relative roles of culture and legal origin”, Journal of International Financial Management and Accounting, Vol. 14 (3); http://dx.doi.org/10.1111/1467646X.00097.

[35]Hossain, M. Momin, M.A. and Leo, S. (2012), "Internet financial reporting and disclosure by listed companies: further evidence from an emerging country", Corporate ownership and control, Vol. 9 (4);

[36] Homayoun S. and Abdul Rahman R. (2010), "determinants of webbased corporate reporting among top public listed companies in $\mathrm{Ma}$ laysia", international journal of Arts and sciences, Vol. 3 (13), pp 187-212;

[37]Hossain, M., Perera M.H.B. and Rahman, A.R. (1995), "Voluntary Disclosure in the Annual Reports of New Zealand Companies", Journal of International Financial Management and Accounting, Vol. 6 (1), pp. 69-85; http://dx.doi.org/10.1111/j.1467-646X.1995.tb00050.x.

[38]Hurtt, D., Kreuze, J., \& Langsam, S. (2001). "Using the Internet for Financial Reporting", The Journal of Corporate Accounting \& Finance, Vol. 12 (3), pp. 67- 76; http://dx.doi.org/10.1002/jcaf.8

[39]Jensen, M., and Meckling, W. (1976), "Theory of the firm: Managerial behaviour, agency costs and ownership structure", Journal of Financial Economics Vol. 3, pp. 305-360; http://dx.doi.org/10.1016/0304-405X (76)90026-X.

[40] Jaggi B. and Low P. Y. (2000), "Impact of culture, market forces, and legal system on financial disclosures", The International Journal of Accounting, Vol. 35, pp. 495-519; http://dx.doi.org/10.1016/S00207063 (00)00076-5.

[41]Kelton A.S. and Yang Y-W. (2008), "The impact of corporate governance on Internet financial reporting", Journal of Accounting and Pub$\begin{array}{lllll}\text { lic Policy, } & \text { Vol. } & \text { 27, } & \text { pp. } & \end{array}$ http://dx.doi.org/10.1016/j.jaccpubpol.2007.11.001.

[42]Kennedy, P. (1985), "A Guide to Econometrics", second edition. The MIT Press, Cambridge;

[43]Lang, M. and R. Lundholm, (1993), "Cross-sectional Determinants of Analyst Ratings of Corporate Disclosures", Journal of Accounting Research, Vol. 31, pp. 246-271; http://dx.doi.org/10.2307/2491273.

[44]La Porta, R., Lopez-De-Silanes, F. and Shleifer, A. (1999) "Corporate Ownership around the World”. Journal of Finance, Vol. 54, pp. 471517; http://dx.doi.org/10.1111/0022-1082.00115

[45]Leventis, S. and Wettman, P. (2004), "Voluntary disclosures in an emerging capital market: some evidence from the Athens Stock", Advances in International Accounting, Vol. 17, pp. 227-250; http://dx.doi.org/10.1016/S0897-3660 (04)17011-6.

[46]Lewis-Beck M.S. (1991), "Applied regression, an introduction", Series quantitative applications in the social science, Sage University Paper;

[47]Lopes, P. T. and Rodrigues, L.L. (2007), "Accounting for financial instruments: An analysis of the determinants of disclosure in the Portuguese stock exchange", The International Journal of Accounting, Vol. 42, pp. 25-56; http://dx.doi.org/10.1016/j.intacc.2006.12.002.

[48] Marston, C. and Polei, A. (2004), "Corporate Reporting on the Internet by German Companies", International Journal of Accounting Information Systems, Vol.5 (3), pp. 285-311; http://dx.doi.org/10.1016/j.accinf.2004.02.009.

[49]Marston, C. L. and P. J. Shrives. (1996), "A review of the development and use of explanatory models in financial disclosure studies", Paper presented at the 19th Annual European Accounting Association Congress, Norway.

[50] Oyelere P., Laswad F. and Fisher R., (2003), "Determinants of Internet financial reporting by New Zealand companies", Journal of International Financial Management and Accounting, Vol.14 (1), pp. 26 63; http://dx.doi.org/10.1111/1467-646X.00089.

[51]Paturel, R., Matoussi, H. and Jouini, S (2006) "Les motivations de la communication financière des entreprises françaises et britanniques à 
travers le web", 5ème Colloque International de la recherche en sciences de gestion, Hammamet, Tunisie, Mars

[52]Pervan I. (2006), "Voluntary Financial Reporting on the Internet Analysis of the Practice of Stock-Market Listed Croatian and Slovene Joint Stock Companies", Financial Theory and Practice, Vol. 30 (1), pp. 1-27;

[53]Pirchegger B. and Wagenhofer A. (1999), "Financial information on the internet: a survey of homepages of Austrian companies". European Accounting Review, Vol. 8(2), pp. 383-95; http://dx.doi.org/10.1080/096381899336113.

[54]Prabowo B. and Tambotoh J.J.C., (2005), "Internet financial reporting as a voluntary disclosure practice : an empirical analysis of Indonesian manufacturing firms using order logit regression", Journal akuntansi and bisnis, Vol.5 (2), pp. 149-160;

[55]Raffournier B. (1995), "The Determinants of Voluntary Financial Disclosure by Swiss Listed Companies", The European Accounting $\begin{array}{lllll}\text { Review, } & \text { Vol. } & 4 & \text { (2), } & \text { pp. }\end{array}$ http://dx.doi.org/10.1080/09638189500000016.

[56]Rogers, E. M. (1962), Diffusion of innovations, Glencoe, Free Press. Rogers, E. M. (1995). Diffusion of innovations, New York: The Free Press.

[57]Salter S. B. and Doupnik, T. S. (1992). "The relationship between legal systems and accounting practices: a classification exercise", $A d$ vances in International Accounting, Vol. 5, pp. 3-22;

[58] Schadewlitz H. J. and Blevins D. R. (1998), "Major Determinants of Interim Disclosures in an Emerging Market", American Business Review, Vol. 16, pp. 41-55;

[59]Trabelsi S., Labelle R. and Dumontier P. (2008), "Incremental voluntary disclosure on corporate websites, determinants and consequences", Journal of Contemporary Accounting \& Economics, Vol. 4 (2), pp. 2-30; http://dx.doi.org/10.1016/S1815-5669 (10)70032-1.

[60]Turel A. (2010), "The Expectation Gap in Internet Financial Reporting: Evidence from an Emerging Capital Market", Middle Eastern Finance and Economics, Vol. 8;

[61]Wallace R., Naser K., and Mora A. (1994), "The Relationship between the comprehensiveness of corporate annual reports and firm characteristics in Spain”, Accounting and Business Research, Vol. 25 (97), pp. 41-53; http://dx.doi.org/10.1080/00014788.1994.9729927.

[62] Wallace R. and Naser K.(1995), "Firm-specific determinants of comprehensiveness of mandatory disclosure in the corporate annual reports of firms on the stock exchange of Hong Kong", Journal of Accounting Public Policy, Vol. 14 (4), pp. 311-68; http://dx.doi.org/10.1016/0278-4254(95)00042-9.

[63]Watson A, Shrives PH, Marston C (2002), "Voluntary disclosure of accounting ratios in UK". British Accounting Review, Vol. 34, pp 289313; http://dx.doi.org/10.1006/bare.2002.0213.

[64]Xiao J.Z. Yang H. and Chow C.W. (2004), "The Determinants and Characteristics of Voluntary-based Disclosures by Listed Chinese Companies", Journal of Accounting and Public Policy, Vol.23 (3), pp. 191-225; http://dx.doi.org/10.1016/j.jaccpubpol.2004.04.002.

[65]Zikmund W.G, Babin B.J, Carr J.C, Griffin M. (2010), Business Research Methods, South-Western CENAGE Learning, Eighth Edition;

[66]Zarzeski, M.T. (1996), Spontaneous harmonization effects of culture and market forces on accounting disclosure practices, Accounting $\mathrm{Ho}$ rizons, Vol. 10, pp. 18-37. 